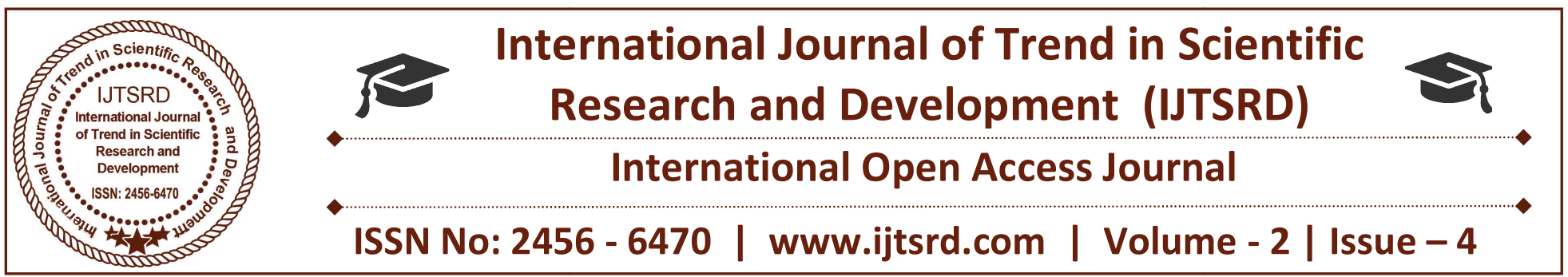

\title{
Construction of Low-Cost Straw Bale House with Regard to Environmental Management in Myanmar
}

\author{
Myint Aung ${ }^{1}$, Aung Lay Tin ${ }^{2}$ \\ ${ }^{1}$ Lecturer, ${ }^{2}$ Professor \\ ${ }^{1,2}$ Department of Mining Engineering, Yangon Technological University, \\ Yangon, Myanmar
}

\section{ABSTRACT}

The unique properties possessed by the Low-Cost Straw Bale (LCSB) make attractive materials candidate for variety of application in Myanmar. Several factors such as type of reinforcement, fabrication technique, and matrix composite provide a huge potential for this material to be tailored for particular application. Straw bale houses are built all over the world due to their low cost and other advantages. They can be built by mixing the straw bale in the field which will be burned later with clay, sand and lime in the place of bricks usually constructed with timber and bricks. In this paper, the measurement of test building of straw bale house were 36 feet long, 24 feet wide and 12 feet high. Nonstructural bale (In-fill Method) was used in construction of straw bale building. It was located in the ShwePyauk Village, Kyauk Tan Township, Thanlyin District, Yangon, Myanmar. That location was closed to the Thanlyin - Kyauk Tan industrial zone and Thilawa Special Economic Zone.

The results indicate that the mechanical properties of the low cost building by using straw bale composite, including creep test, short-term static load deformation and sustainable construction materials as a potential candidate by resulting in saving of material, cost, and energy. This straw bale house is environmental friendly low cost housing and very useful for rural area.

Keywords: Straw bale house, Composite material, Reinforcement, Brick.

\section{INTRODUCTION}

The rapid development of the technology in each industry field such as automobile, aerospace, transportation and numerous applications has prompt the invention of new materials to meet the ever increasing demand of outstanding properties to replace the convention monolithic materials [1]. However, the low-cost conventional construction materials have limitations to possess excellent combination of mechanical properties such as high strength, high stiffness, and high toughness with low density [2]. Evolution of the understanding regarding the behavior of materials and technology for searching more advance candidate material had led to the composite ages [3]. The high performances composites which have been developed are such as Ceramic Matrix Composites (CMC), Metal Matrix Composites (MMC) and Polymer Matrix Composites (PMC)[4]. In this research, composite material consists of straw bale and chemical composition cellulose, two or more constituent (matrix and reinforcement) with significant different properties which give the composites unique properties.

It becomes strong stalk of tall grain plants growing, such as, wheat, hemp or rice-that remains in the field after the seed grains have been harvested. The reinforcement phase usually possesses higher stiffness and strength which serve to enhance the mechanical properties of the matrix phase to produce a desire composite material [5]. 
The objectives of the present work are to investigate the environmental friendly low cost housing plan for rural area and sustainable mechanical properties of composite low-cost straw bale houses.

The structures of this study are as follow: Section II presented method of analysis for straw bale house. Results and discussions are indicated in Section III. In Section IV, how to construct the straw bale house and conclusions are presented in Section V.

\section{METHODS OF ANALYSIS}

\section{A. Composite Straw Bale House}

The use of plastered based straw bale building is one of the finest renewable materials replacements. It is strong stalk of tall grain plants - such as wheat, rye, hemp or rice. Straw is one of that remains in the field after the seed grains have been harvested. Its chemical composition is primarily cellulose, just like trees. When bundled into a bale it becomes a solid block that is highly resistant to decomposition. When covered with a plaster skin, strong, energy efficient and ecologically sound house.

\section{B. Bailing Methods}

There are two methods in bailing straw. These are two stringers and three stringers methods. Two stringers are roughly 18 inches wide, 14 inches high and 36 inches long and three stringers are roughly 24 inches wide, 16 inches high and 48 inches long as shown in Figure 1.

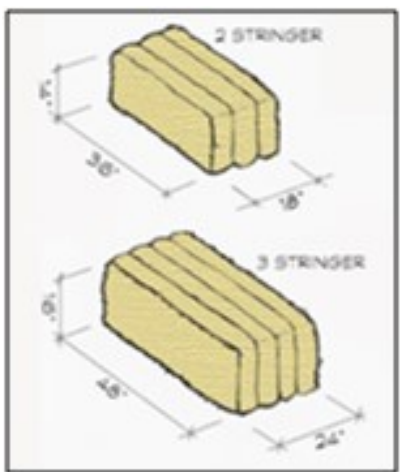

Fig. 1 Types of Straw Bailing

Both types of bailing were used in this test straw bale house. After making bundle of straw bale, mechanical testing was tested.

\section{Testing of Mechanical Properties \\ 1. Creep Test}

In preparation for static testing to failure two of the test walls were subject to a dead loading of 16.6 $\mathrm{kN} / \mathrm{m}^{2}$, In that Figure 1, Vertical settlement of the panels was measured periodically for up to standard period 74 days.

\section{Static Load Test}

All five wall panels were examined for the static loading in vertical compression. Constant loading was applied incrementally through two five tons hydraulic jacks for the failure components (Figure 3). The applied load was recorded using five tons digital load cells. The load was transferred directly to the straw bales through the timber wall transferred directly to the straw bales through the timber was plate. Figure 3 shows that the Vertical displacement of the straw bales was recorded using two linear voltage displacement transducers (LVDTs), placed centrally across the width of the plate. Lateral buckling displacements under loading were also recorded using either LVDTs by direct taping measurement. The average increment rate of loading for the failure position was between 0.30 and $0.73 \mathrm{kN} / \mathrm{min}$. In between each increment lateral displacement was measured by taping and noting the general condition of the wall.

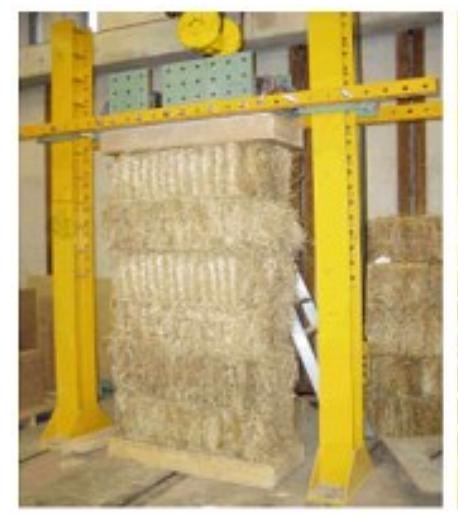

Fig. 2 Settlement test set up

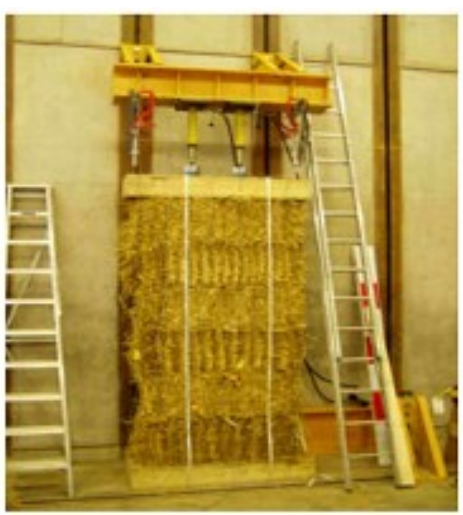

Fig. 3Static Load Test
3. Construction Methods of Straw Bale Building Wall

There are three main methods to build with straw bale such as structural bale (Nebraska-style), Light-weight frame and non-structural bale (in-fill method) as shown in Figure 4.

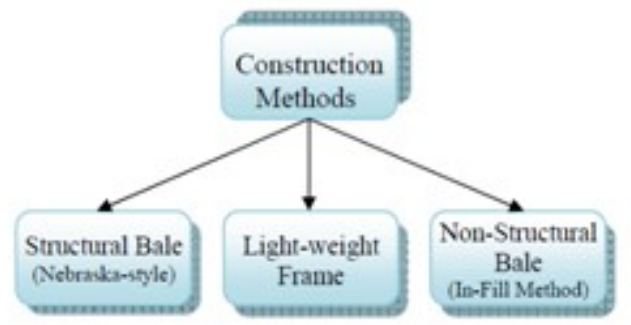

Fig. 4 Methods of straw bale construction 
Among the straw bale construction methods, nonstructural bale (in-fill method) is used because of easy to build and greater stability for window and door frame than load bearing style.

\section{RESULTS AND DISCUSSIONS}

\section{Creep Test Results}

In the beginning of the test, the load was increased in three stages. Initially a load of $330 \mathrm{~kg}$ was applied, followed by a further $300 \mathrm{~kg}$ after 13 days and a further $210 \mathrm{~kg}$ after 20 days. On application of each load there was an instantaneous deformation. During application of each load increment the instantaneous stiffness of the bale wall did not significantly vary $(15-19 \mathrm{kN} / \mathrm{mm})$. Following each load increment settlement increased under constant loading, through the rate of settlement gain generally decreased with time. The greatest rate of settlement was recorded during the first two days after load application, thereafter slowing down to an average of between 0.2 and $0.9 \mathrm{~mm} /$ day. On removal of the load after 70 days there was an instant recovery of $22 \mathrm{~mm}$, followed by further $10 \mathrm{~mm}$ over the following 4 days, by which time the test was terminated. There was subsequently tested under short-term static loading to failure. In the second test, a total service loading of $840 \mathrm{~kg}$ was applied in one increment. The initial stiffness of the wall, $17 \mathrm{kN} / \mathrm{mm}$, was similar to the first test wall response. As before the deformation increased with time. The greatest rate of creep deformation was also recorded during the first two days after loading and thereafter the rate of settlement wad approximately $0.5 \mathrm{~mm} /$ day over the following three weeks. Settlement of the wall had not ceased after 23 days when the test was ended. Figure 5 shows that load settlement tests, the wall was subsequently strapped with polypropylene strapping and lime rendered before load testing failure.

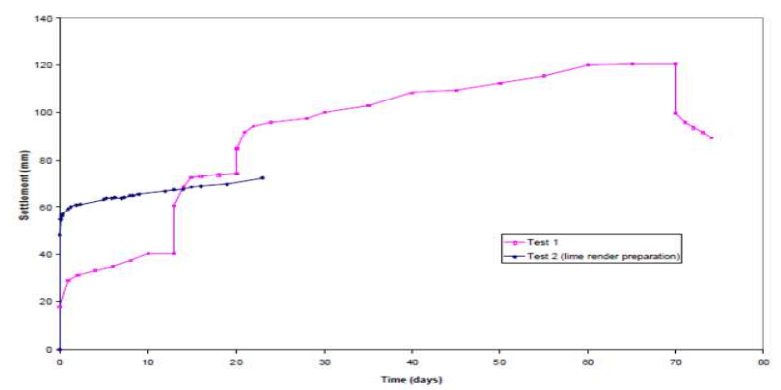

Fig.5 Load Settlement Test

The deformation presented a represent average settlement of the wall. For example, in the second wall the settlement was approximately $50 \%$ greater on one side arising from unequal deformation of the upper-most bale, most likely caused by inconsistent bale density. The recorded creep behavior described above is also likely to have been influenced by variations in the temperature and humidity conditions in the laboratory temperature varied between $10^{\circ} \mathrm{C}$ and $23^{\circ} \mathrm{C}$ during testing, relatives humidity varied approximately between $30 \%$ and $70 \%$.

\section{Static Load Test Results}

The short-term static load-deformation responses of the test walls were shown in Figure 6.

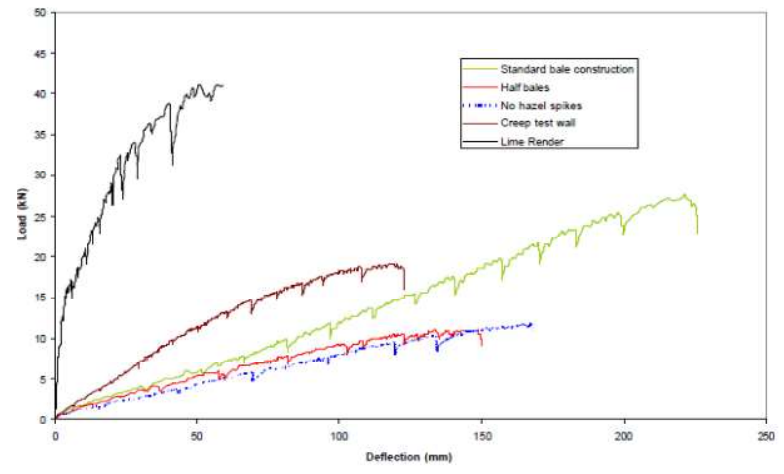

Fig.6 Static Load Tests

Table 1 shows the summarizing of initial wall stiffness, maximum applied loads and total settlements. Initial was stiffness was recorded by the recorded total settlement under a service load of 9.5 $\mathrm{kN}\left(19.2 \mathrm{kN} / \mathrm{m}^{2}\right)$. The load reduction recorded in some walls at each increment occurred during measurement of lateral displacement and inspection of the wall.

Figure 7 shows all unplastered walls failed by overall buckling, though variations in bale density, especially in the upper most bale, led to significant unequal compression of the top plate in a number of tests (see in Figure 8). Recorded deformation in Figure 4 and 5represent averaged values. In General, the stiffness decreased as their maximum load approached and the walls buckled in compression.

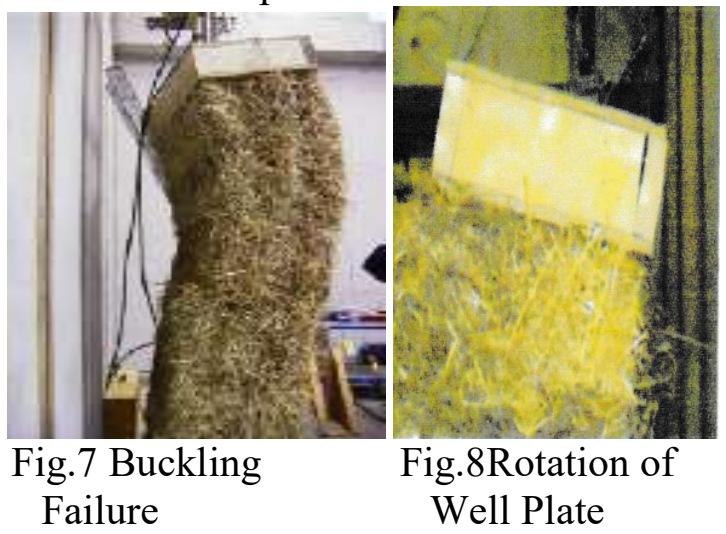


The standard bale construction wall settled under load increasing with little change in stiffness until a maximum load of $27.6 \mathrm{kN}$ was reached. As expected the initially pre- compressed wall exhibited increasing stiffness compared to the standard construction as shown in Table 1. Though the maximum load was reduced although higher than both the half bale and no hazed wall tests.

TABLE1. Static Load test results

\begin{tabular}{|l|c|c|c|}
\hline \multicolumn{1}{|c|}{ Wall } & $\begin{array}{c}\text { Initial } \\
\text { wall } \\
\text { stiffiness } \\
(\mathrm{KN} / \mathrm{mm})\end{array}$ & $\begin{array}{c}\text { Maximum } \\
\text { applied } \\
\text { load(KN) }\end{array}$ & $\begin{array}{c}\text { Settlement } \\
\text { at } \\
\text { maximum } \\
\text { load (mm) }\end{array}$ \\
\hline $\begin{array}{l}\text { Standard } \\
\text { construction }\end{array}$ & 0.11 & 27.6 & 220 \\
\hline $\begin{array}{l}\text { Pre- } \\
\text { compressed } \\
\text { wall }\end{array}$ & 0.22 & 19.2 & 120 \\
\hline Half-bales & 0.087 & 10.9 & 140 \\
\hline $\begin{array}{l}\text { No hazel } \\
\text { spikes }\end{array}$ & 0.077 & 11.7 & 165 \\
\hline $\begin{array}{l}\text { Lime } \\
\text { rendered } \\
\text { wall }\end{array}$ & 5.62 & 41.1 & 55 \\
\hline
\end{tabular}

The wall built with half bales showed a significant reduction in maximum load and initial stiffness. The half bales were not as dense as the original bales and the inclusion of vertical joints in alternative courses was also expected to impair stiffness and strength. Table 1 presents the condition of the maximum applied load on the wall. Removal of hazel spikes from wall construction had a significant impact on both wall stiffness and load capacity. Hazel spikes contribute to wall resistance to friction force which passes through the bales, evident by the difficulty in driving them during construction.

The addition of render or plaster coats to straw bale changes mechanical properties. The mush stiffer and stronger render outer coats attract a much greater proportion of the vertical loading, resulting in a more complex composite sandwich form of construction. The involving of render coats of the strength and stiffness of straw bale wall had shown significant consequences for the construction and maintenance of render coats.

The maximum loads and initial stiffness of the walls were comparable reported with previous report $(1,2)$. The maximum loads for unplastered straw bale walls were reported at between 4.2 and $19.2 \mathrm{kN} / \mathrm{m}^{2}$, depending on bale type, orientation and the use of internal reinforcing bars. Maximum load of unplastered walls were reported with variation from 72 to $198 \mathrm{~mm}$. For the maximum loads for plastered bale walls were reported variation from 21 to 66 $\mathrm{kN} / \mathrm{m}^{2}$.

A maximum permissible service load of approximately $19 \mathrm{kN} / \mathrm{m}^{2}(9.6 \mathrm{kN})$ was used in straw bale wall design. The maximum applied load of the lime rendered wall was over four times greater. However, the maximum load of one unplastered wall was only $13 \%$ higher, though the standard bale wall achieved a maximums loading nearly three times higher.

\section{Failure Results}

Lime rendering of the wall had greatest on strength and stiffness. Initial stiffness was increased by over 50 times and maximum applied load by nearly $50 \%$. Stiffness of the wall under load decreased noticeably at around $15 \mathrm{kN}$ as the lime rendered cracked and the wall is failed. In Figure 9, though the lime render was applied to the straw bales outside the full width of the top bearing plate, a slight bearing of the top plate onto the edge of the render of one side resulted in unequal settlement of the top plate contributing to the observed failure mode. Local buckling of the plaster, bearing failure of the plaster was also observed.

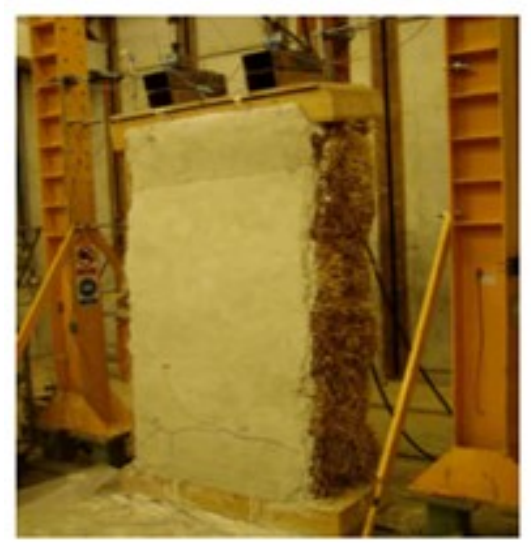

Fig. 9 Lime rendered wall failure

\section{IV.CONSTRUCTION OF TEST STRAW BALE HOUSES}

After testing foe mechanical properties of straw bale, test building was built in selected site. The following Figures were shown for construction procedures of test building. 

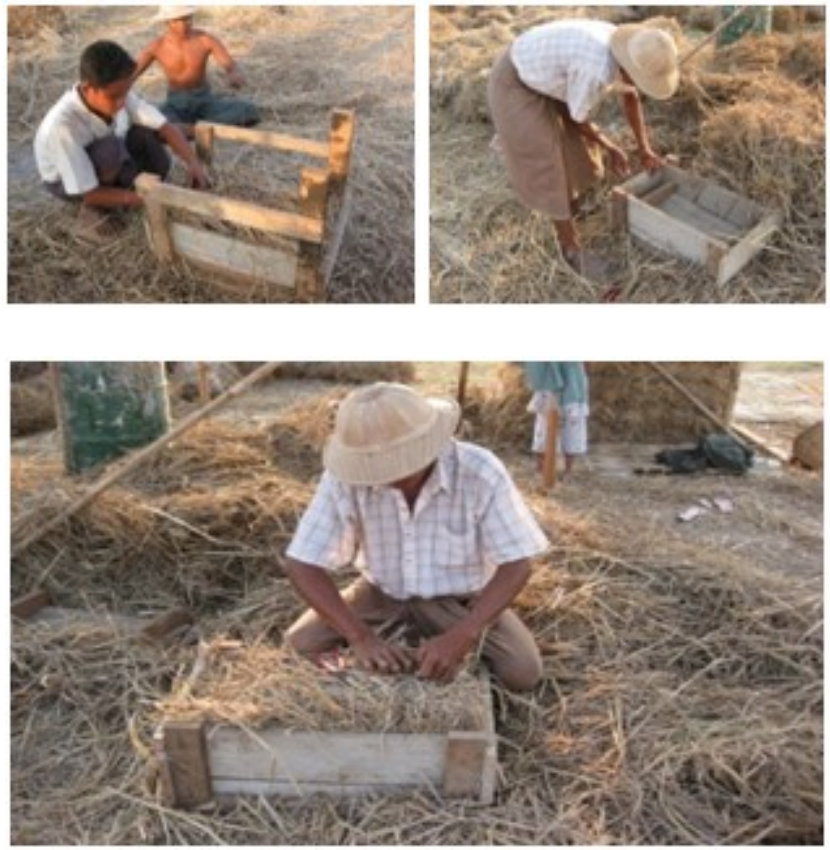

(a) Practical Straw Bailing

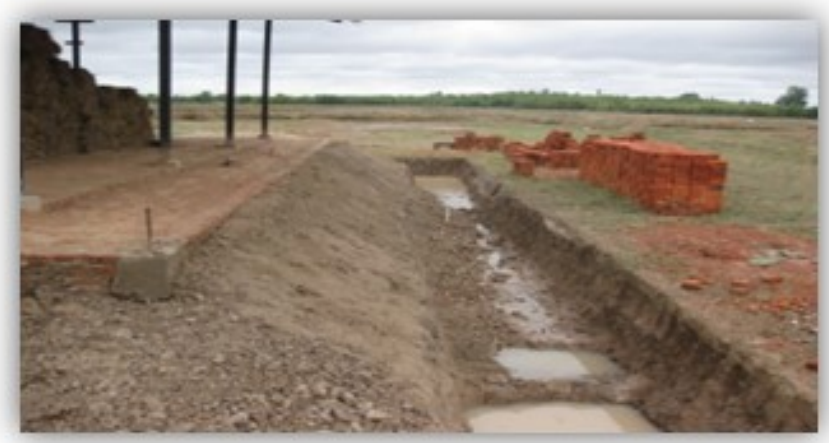

(b) Construction of Foundation
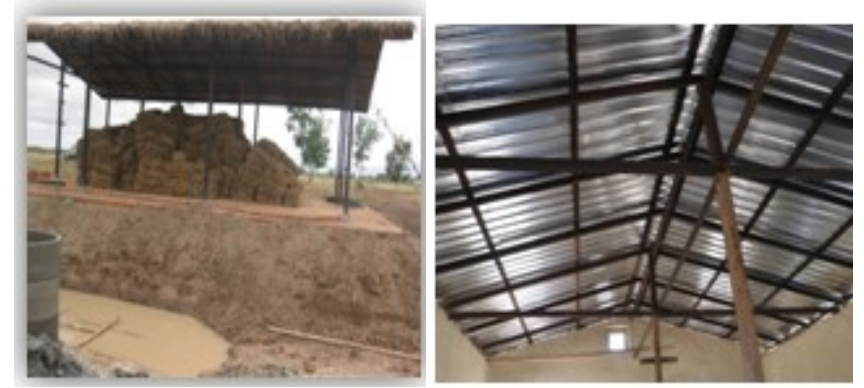

(C) Fixing of Post and C.G.I Sheet Roofing

Fig. 10 Step by Step of Construction for Straw Bale House

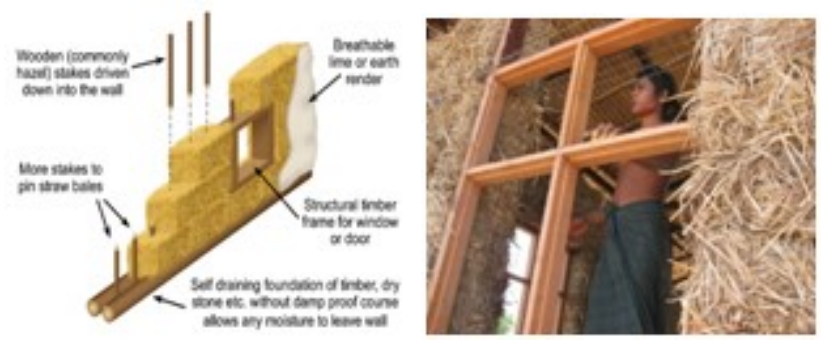

(d)Construction of Straw Bale Walling and Fixing of Windows Frames
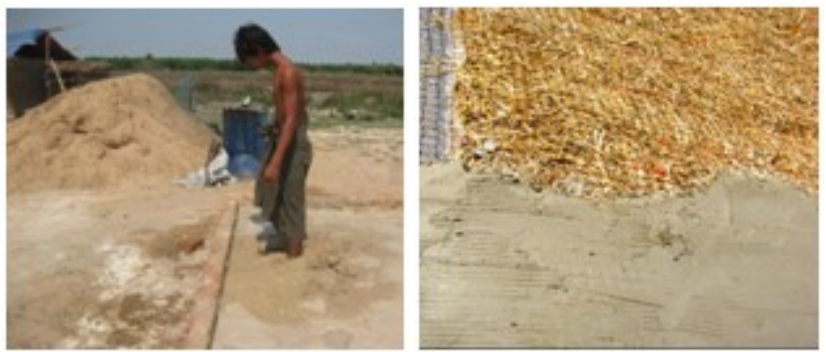

(e)Plastering in (1:3) Lime Mortar

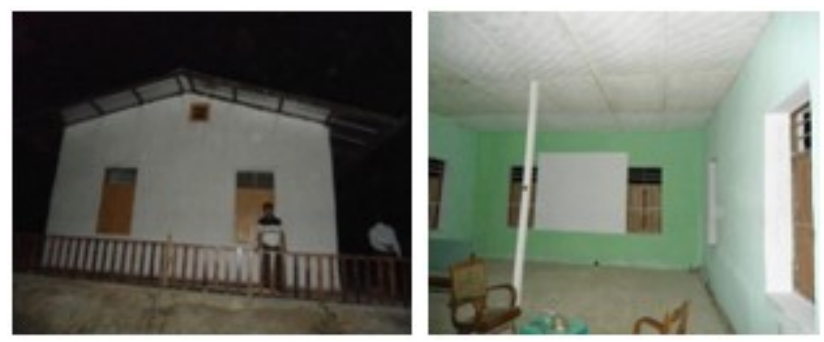

(f)Ceiling and Painting

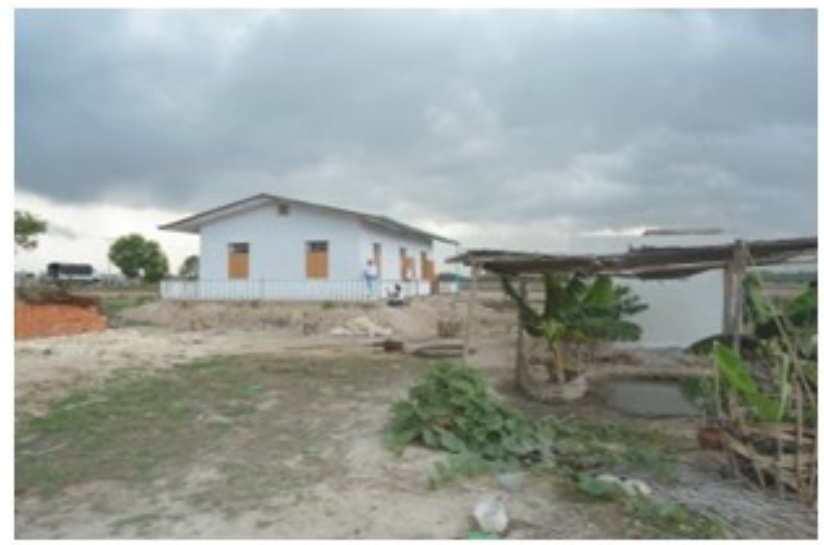

(g)Vegetation of Surround of Building

After construction of straw bale house, indoor and outdoor temperature are measured during summer and winter seasons. This results show that straw bale house is colder than brick noggin in summer season and warmer than in winter season. Cost of straw bale house and $4 \frac{1}{2}$ " thick brick noggin was estimated for comparison. The following Table 2 shows the comparison between $4 \frac{1}{2}$ " thick brick noggin walling and 12" thick straw bale walling. It can be found that cost of straw bale house is less than twice of brick nogging walling. 
Table2. Comparison between 41/2" Thick Brick NoggingWalling and 12" Thick Strawbale Walling

\begin{tabular}{|c|l|c|c|c|}
\hline Type & \multicolumn{1}{|c|}{ Particular } & $\begin{array}{c}\text { Material, } \\
\text { Cost (Ks) }\end{array}$ & $\begin{array}{c}\text { Labour } \\
\text { Cost (Ks) }\end{array}$ & $\begin{array}{c}\text { Total } \\
\text { Cost (Ks) }\end{array}$ \\
\hline (A) & $\begin{array}{l}4 \frac{1}{2} \text { " Thick Brick Nogging } \\
\text { Waling in Cement Mortar 1:3 }\end{array}$ & 87875 & 44000 & 131875 \\
\hline (B) & $\begin{array}{l}\text { 12" Thick Strawbale Block } \\
\text { Walling with Sq.mesh }\end{array}$ & 43600 & 21000 & 64600 \\
\hline & Defference & 44275 & 23000 & 67275 \\
\hline
\end{tabular}

\section{CONCLUSIONS}

Finally, the conclusion for this paper are (a) reducing the carbon emission due to the reduction of the cement using (b) studying of the mechanical behaviour of the materials which depend on the design of the wall making (c) saving the environmental effect.

Therefore, this straw bale house is environmental friendly low cost building and very useful for rural area.

\section{ACKNOWLEDGEMENT}

The author would like to deeply thank to Professor Dr.MyoNyunt, Head, Department of Mining Engineering, Technological University, Monywa for his keeping encouraging to produce this paper. And also, thanks to Dr.KyawSwar Tint, Professor, Department of Mining Engineering and Dr. Aung Lay Tin, Professor and Head, Department of Mining Engineering, Yangon Technological University.

\section{REFERENCES}

1. K.sheprd, "Straw Bale Home Basics" Boulder Company, USA, 2006.

2. Mohamed Salah GharibElsayed, "Straw Bale is Future House Building Material”, Egypt, 2006.

3. C. Keefe, "Straw Bale Design-Choosing the Right Size Straw Bales", 2007.

4. Dr. MyoNyunt, "Building construction by using Straw Bale", Myanmar Engineering Society, Tech- Digest, October, 2010. 